\title{
A semi-quantitative RT-PCR method to measure the in vivo effect of dietary conjugated linoleic acid on porcine muscle PPAR gene expression
}

\author{
W.J. Meadus ${ }^{1 *}$
}

\author{
${ }^{1}$ Meat Research Section, Agriculture and Agri-Food Canada, Lacombe Research Center, 6000 C\&E Trail, Lacombe, Alberta, \\ Canada T41 1W1.
}

*To whom correspondence should be addressed. E-mail: meadusj@em.agr.ca

Submitted: November 1, 2002; Revised: December 16, 2002; Accepted: January 9, 2003; Published: February 17, 2003

Indexing terms: RT-PCR, PPAR, gene expression, in vivo, pigs, muscle

\begin{abstract}
Conjugated linoleic acid (CLA) can activate (in vitro) the nuclear transcription factors known as the peroxisome proliferators activated receptors (PPAR). CLA was fed at $11 \mathrm{~g}$ $\mathrm{CLA} / \mathrm{kg}$ of feed for $45 \mathrm{~d}$ to castrated male pigs (barrows) to better understand long term effects of PPAR activation in vivo. The barrows fed CLA had lean muscle increased by $3.5 \%$ and overall fat reduced by $9.2 \%$ but intramuscular fat (IMF \%) was increased by $14 \%(P<0.05)$. To measure the effect of long term feeding of CLA on porcine muscle gene expression, a semi-quantitative RT-PCR method was developed using cDNA normalized against the housekeeping genes cyclophilin and $\beta$ actin. This method does not require radioactivity or expensive PCR instruments with real-time fluorescent detection. PPAR $\gamma$ and the PPAR responsive gene AFABP but not PPAR $\alpha$ were significantly increased $(P<0.05)$ in the CLA fed pig's muscle. PPAR $\alpha$ and PPAR $\gamma$ were also quantitatively tested for large differences in gene expression by western blot analysis but no significant difference was detected at this level. Although large differences in gene expression of the PPAR transcriptional factors could not be confirmed by western blotting techniques. The increased expression of AFABP gene, which is responsive to PPAR transcriptional factors, confirmed that dietary CLA can induce a detectable increase in basal PPAR transcriptional activity in the live animal.
\end{abstract}

\section{INTRODUCTION}

In 1997, Dugan and coworkers (1) reported that Conjugated Linoleic acid (CLA) acted as effective fat to lean "repartitioning" agent in swine. Adding CLA to $2 \%$ of the feed, increased lean muscle by $2.3 \%$ while reducing overall subcutaneous fat $6.8 \%$ in genetically lean, Large White pigs. In vitro studies using cell cultures have demonstrated that CLA acts as an agonist of the peroxisome proliferator activated receptor family (PPAR). PPARs are DNA binding transcription factors that bind the peroxisome proliferator repeat element (PPRE) $(2,3,4)$ as a heterodimer with the retinoic acid receptor $(\mathrm{RxR})$, which is activated by 9-cis-retinoic acid (vitamin A) $(5,6)$. The PPAR family is currently divided into three subgroups, $\alpha, \beta$ and $\gamma$. PPAR $\beta$ is expressed throughout the body and is involved in embryo development $(7,8)$. PPAR $\alpha$ has a 1000-fold higher affinity for CLA than PPAR $\gamma$ and both are expressed in hepatic, muscle, pancreatic, and adipose tissue.

Total RNA was prepared from pig muscle samples to examine if the CLA induced physiological changes were by differences in gene expression. The mRNA amount of a transcriptional factor such as PPAR $\gamma$ is often relatively very low and difficult to detect using standard Northern blot procedures. As a result, Northern blot methods usually require additional time consuming selective chromatography to isolate poly $\mathrm{A}+$ mRNA and radioactive labeled probes to generate a measurable signal to quantify. Therefore, in order to reduce labor, a semi-quantitative RT-PCR method was developed. RT-PCR is the most sensitive method for detecting gene transcription products; however, it can be highly variable and may not accurately reflect gene activity (9). Subsequently, western blotting was used to quantitatively measure total PPAR protein. Ultimately however, even protein levels may not reflect actual gene activity due to post-translational modifications; therefore, the PPRE responsive genes, adipocyte fatty acid binding protein (AFBAP) and acyl Co A oxidase (ACO), were measured to confirm PPAR activity with its transcription rate.

Often a direct link cannot be made between a physiological response and a genetic marker due to missing biochemical

C 2003. Biological Procedures Online. Published in Biological Procedures Online under license from the author(s). Copying, printing, redistribution and storage permitted.

Biological Procedures Online • Vol. 5 No. 1 • February 17, $2003 \bullet$ www.biologicalprocedures.com 
information. Some studies in swine have found that dietary CLA increased fasting levels of serum insulin (10). Insulin increases muscle nutrient absorption. Glutamine:Fructose aminotransferase (GFAT) is the rate-limiting enzyme in the hexosamine pathway, which is involved in producing glycosylation substrates (11). GFAT mRNA expression is increased when intercellular concentrations of glucose or fatty acids are high (12). Therefore the expression of GFAT was measured to examine if the increase lean mass in pigs fed CLA was due to more available energy inside the muscle cells.

\section{MATERIALS AND METHODS}

\section{Animal treatments}

Muscle samples from 20 castrated male Landrace X Large White pigs (barrows) were used in this study (1). The pigs were fed either a CLA supplemented diet containing $2 \%$ conjugated linoleic acid $(n=10)$ or a Control diet containing $2 \%$ sunflower oil $(n=10)$. The isomeric composition of the CLA feed has been previously reported (13). The diets were formulated to meet nutrient requirements as outlined by the National Research Council (14). The feeding trial commenced when the pigs reached an average weight of $60 \mathrm{~kg}$ and lasted for 45 days. The pigs were slaughtered at an average weight of $105 \mathrm{~kg}$, as outlined in Dugan (1). The animals were slaughtered at the Lacombe Research Center in accordance with the principles and guidelines set by the Canadian Council on Animal Care (15). Animal carcass evaluations for lean muscle (Lean) and subcutaneous fat (SQ) levels were calculated from in-depth dissections according to the procedures described by Martin (16). Intramuscular fat \% (IMF \%) was estimated from dried ground longissimus thoracis (LT) muscle (Method 39.1.05: AOAC 1995) (17).

\section{RNA Isolation}

Total RNA was isolated from $100 \mathrm{mg}$ of longissimus thoracis (LT) muscle cores using the guanidine isothiocyanate based TRIzol solution (GIBCO-BRL, Burlington, ON, Canada) according to the manufacturer's specifications (18). The RNA samples were resuspended in $100 \%$ formamide and quantified spectrophotometrically at $260 \mathrm{~nm}$. All RNA isolates had an $\mathrm{OD}_{260}: \mathrm{OD}_{280}$ between 1.8 and 2.0, indicating clean RNA isolates. The RNA quality was also checked by $1.0 \%$ agarose gel electrophoresis, stained with $1 \mathrm{ug} / \mathrm{ml}$ ethidium bromide. Genomic DNA was isolated from the meat samples using the guanidium based DNAzol solution (GIBCO-BRL, Burlington, ON, Canada) as outlined in Meadus and MacInnis (19).

\section{Relative Reverse Transcriptase - Polymerase Chain Reaction (RT-PCR) analysis}

A two-step semi-quantitative RT-PCR method was used to measure gene expression in the LT muscle samples at the time of slaughter. Oligo- $(\mathrm{dT})_{10 \mathrm{n}}$ (InVitrogen, Burlington ON) was used as primer in the first step of cDNA synthesis. Total RNA $(5 \mu \mathrm{g})$ was combined with $0.5 \mu \mathrm{g}$ oligo-dT, $200 \mu \mathrm{M}$ dNTPs and $\mathrm{H}_{2} \mathrm{O}$ and preheated at $65^{\circ} \mathrm{C}$ for $2 \mathrm{~min}$ to denature secondary structures. The mixture was then cooled rapidly to $20^{\circ} \mathrm{C}$ and then $10 \mu \mathrm{l}$ XX RT Buffer, $10 \mathrm{mM}$ DTT and $200 \mathrm{U}$ MMLV Reverse Transcriptase (Sigma-Aldrich, Oakville, ON, Canada) was added for a total volume of $50 \mu \mathrm{l}$. The RT mix was incubated at $37^{\circ} \mathrm{C}$ for $90 \mathrm{~min}$. then stopped by heating at $95^{\circ} \mathrm{C}$ for $5 \mathrm{~min}$. The cDNA stock was stored at $-20^{\circ} \mathrm{C}$. The yield of cDNA was measured according to the PCR signal generated from the internal standard house-keeping gene cyclophilin [Genebank accession \#AY008846] or $\beta$-actin amplified from 18 to 24 cycles starting with $0.1 \mu$ of the cDNA solution. The volume of each cDNA pool was adjusted to give the same exponential phase PCR signal strength for $\beta$-actin after 20 cycles.

Relative RT-PCR (20) was performed to measure gene expression of PPAR $\alpha$, PPAR $\gamma$, AFABP, GFAT, ACO, and mcalpain mRNAs. Primer sequences and optimal PCR annealing temperatures (ta) and are listed in Table 1. To insure that no false positive PCR fragments would be generated from pseudogenes in contaminating genomic DNA; primer sequences were designed to span intron regions, when genomic sequence data was available. In addition, all PCR primer combinations were tested using porcine genomic DNA as a negative control. Polymerase chain reactions were performed on a PTC-200 PCR machine (MJ Research Inc, MA, USA) using $\sim 100 \mathrm{ng}$ of cDNA, 5 pmoles each oligonucleotide primer, $200 \mu \mathrm{M}$ of each dNTP, 1 unit of REDTaq Polymerase (Sigma-Aldrich, Oakville, ON, Canada) and 1X REDTaq polymerase buffer in a $20 \mu \mathrm{l}$ volume. The PCR program initially started with a $95^{\circ} \mathrm{C}$ denaturation for $5 \mathrm{~min}$, followed by 28 to 38 cycles of $95^{\circ} \mathrm{C} / 1 \mathrm{~min}$, ta ${ }^{\circ} \mathrm{C} / 1 \mathrm{~min}, 72^{\circ} \mathrm{C} / 1 \mathrm{~min}$. Linear amplification range for each gene was tested on the adjusted cDNA. The less expressed transcripts of PPAR $\alpha$, and PPAR $\gamma$ required $>32$ cycles of PCR for detection. B-actin primers were added when 20 cycles were remaining in the specified gene's linear amplification range. The PCR samples were electrophoresed on $8 \%$ polyacrylamide gels $(8 \mathrm{X} 10 \mathrm{~cm})$ or $2.5 \%$ agarose gels in TBE buffer [ $89 \mathrm{mM}$ Tris-base $\mathrm{pH} 7.6$, $89 \mathrm{mM}$ boric acid, $2 \mathrm{mM}$ EDTA]. The gels were stained with ethidium bromide $[10 \mu \mathrm{g} / \mathrm{ml}]$ and photographed on top of a $280 \mathrm{~nm}$ UV light box. The gel images were digitally captured with a CCD camera and analyzed with the NIH Imager beta version 2 program. The quantity and base pair size of the PCR generated DNA fragments were estimated relative to DNA ladder standards. Densitometry values were measured at each cycle sampling using the One-Dscan software (Scanalytics, Fairfax, VA). RT-PCR values are presented as a ratio of the specified gene's signal in the selected linear amplification cycle divided by the $\beta$-actin signal (Fig. 1). 


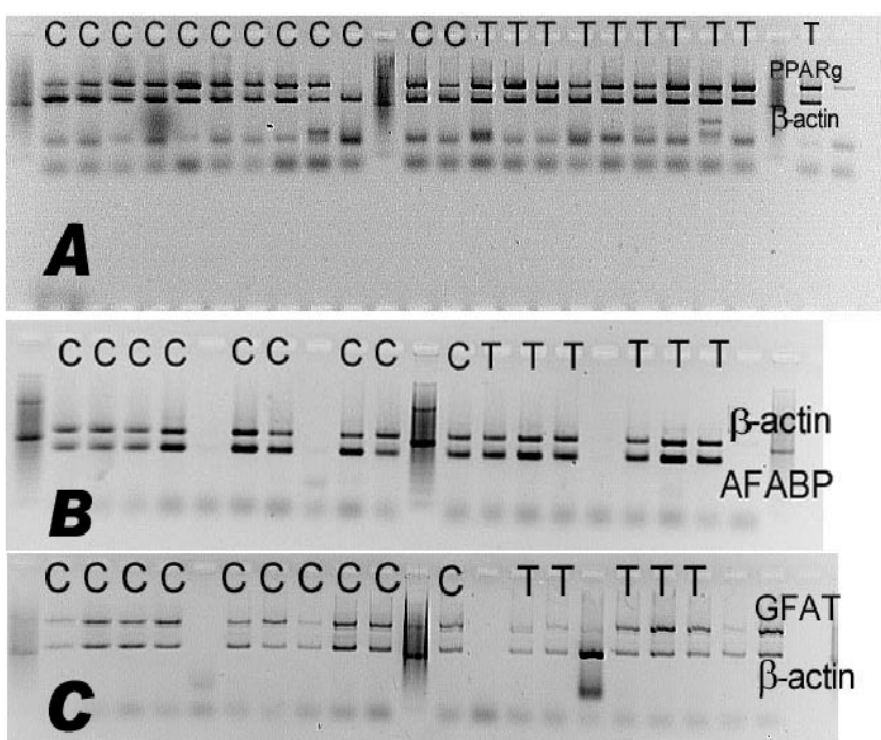

Fig. 1: Gel image of relative RT-PCR for A) PPAR $\gamma(381 \mathrm{bp})$ at 34 cycles with $\beta$-actin (233bp) added at cycle 14 to act as the internal control. B) GFAT (420bp) at 34 cycles with $\beta$-actin added at cycle 14. C) AFABP (147bp) at cycle 26 with $\beta$-actin added at cycle 4 . C; control fed animals. T: CLA fed animals.

\section{Protein isolation and analysis}

Protein extracts were prepared from the thawed muscle samples by homogenizing $100 \mathrm{mg}$ of muscle in $1 \mathrm{ml}$ of extract buffer A [100 mM Tris-HCl pH 7.5, $0.5 \mathrm{mM}$ dithiothreitol, 2 $\mathrm{mM}$ phenymethylsulfonyl fluoride (PMSF), $5 \mathrm{mM}$ ethylenediaminetetraacetic acid (EDTA), $500 \mathrm{mM} \mathrm{NaCl}$, and $0.1 \%$ Triton $\mathrm{X}-100$. The homogenate was then centrifuged at $1000 \mathrm{xg}$ for $5 \mathrm{~min}$ to pellet large cellular debris. Protein concentrations were measured using the BCA method (Pierce, Rockford, IL). Samples were diluted to $1 \mathrm{ug} / \mathrm{ul}$ with extract buffer and then 20 ug were mixed with an equal volume of SDS-PAGE loading buffer [50 mM Tris- $\mathrm{HCl} \mathrm{pH} 6.8,10 \%$ glycerol, $\quad 2 \% \quad$ SDS, $\quad 5 \% \quad \beta$-mercaptoethanol, $\quad 0.002 \%$ bromophenol blue], heated at $90^{\circ} \mathrm{C}$ for 5 min then loaded onto $10 \%$ SDS-PAGE for electrophoresis in TBE. To perform the Western analysis, the separated proteins were electroblotted to Protran nitrocellulose (Schleicher, Schuell, Keene, NH) and then probed with rabbit anti-rat m-calpain (Sigma, St. Louis, MO), rabbit anti-synthetic PPAR (Sigma, St. Louis, MO), and mouse anti-rabbit GAPDH (Chemicon Intl. Inc, Temecula, CA) which acts as an internal standard between samples. The primary antibodies were detected with secondary anti-rabbit or anti-mouse $\operatorname{IgG}$ conjugated with alkaline phosphatase to generate a NBT/BCIP signal (Roche Diagnostics, Laval, PQ). To help in identification, prestained SDS-PAGE protein broad range standards (BioRad, Hercules, CA) were included on the $10 \%$ SDS-PAGE. The protein standards were visible on the Protran western blots. The antibody labeled m-calpain (58kDa), PPAR $\alpha(\sim 54 \mathrm{kDa}), \operatorname{PPAR} \gamma(\sim 55 \mathrm{kDa})$ or GADPH $(\sim 35 \mathrm{kDa})$ polypeptide bands on the developed blots were digitally captured with a HP Scanjet 5100C scanner (Helwett Packard Co., Greeley, CO) and band intensities were measured using the One-D Scan program (Scanalytics, Fairfax, VA). Western blotting gives a more direct quantitative of a gene's expression level but depends on the availability of specific antibodies and is less sensitive than RT-PCR. Protein quantity also doesn't necessarily reflect gene product activity, since the protein or enzyme may still undergo post-translational modifications.

\section{Statistical analysis}

RT-PCR signals were averaged from at least 3 replicates using 2 quantities of cDNA from 10 CLA and 10 Control samples. The RT-PCR ratio values were analyzed using GLM Frequency and Correlation procedures (21). Western blot data was generated from 3 replicate runs using 7 CLA samples and 7 Control samples. Significance was calculated using Student's t-test.

\section{RESULTS AND DISCUSSION}

In this study, barrows fed 2\% CLA enriched oil for $45 \mathrm{~d}$ had a significant reduction in subcutaneous fat (SQ) compared to pigs fed diets containing 2\% sunflower oil. However, 2\% CLA also significantly increased IMF\%. The changes in physiology are believed to be due to CLA activating the nuclear transcription factor PPAR (2). The relationship between IMF and dietary CLA are explained in greater detail in previously published work of Meadus et al. (2002) (22). The relative gene expression level in LT muscle from pigs fed either the control diet or CLA diet is shown in Fig. 2. In the LT muscle of animals fed CLA; GFAT, AFABP, and PPAR $\gamma$ mRNAs were significantly $(\mathrm{P}<0.05)$ increased $36.1 \%, 20.4 \%$ and $26.0 \%$ respectively. However, Western blotting analysis (Fig. 3) could not detect a difference in LT muscle PPAR $\gamma$ protein content between Control and CLA treatments.

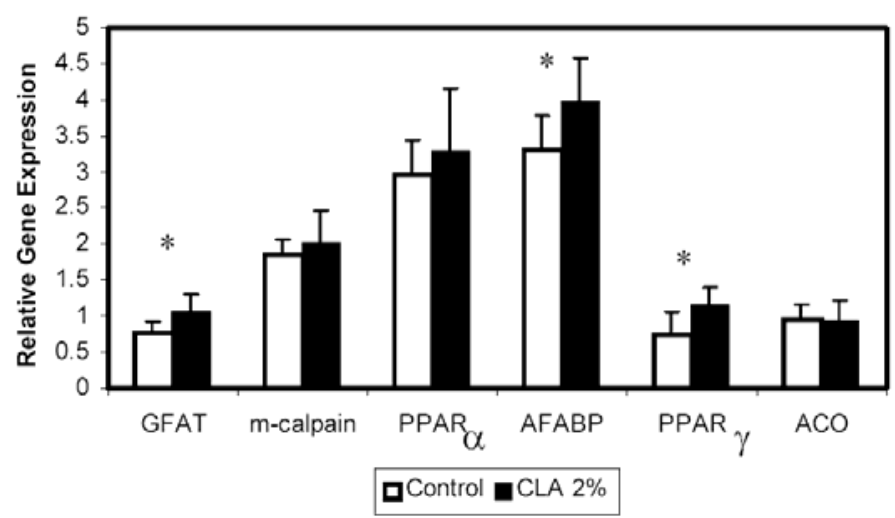

Fig. 2: Adult muscle gene expression in barrows fed CLA $(n=10)$ relative to the Control sunflower diet $(n=10)$. Gene transcript quantity was measured by relative RT-PCR using the internal standard $\beta$-actin RT-PCR signal as the denominator as described in the materials and methods section. Error bars represent standard deviation. Significance is represented as (*) $\mathrm{P}<0.05,(* *) \mathrm{P}<0.01$. 


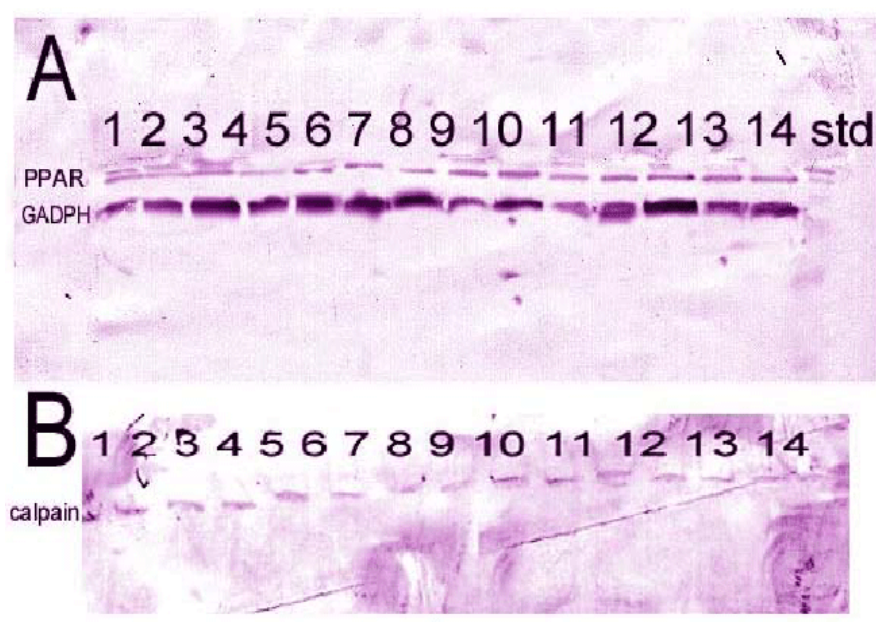

Fig. 3: Western blot of muscle calpain, PPAR $\alpha(53 \mathrm{kDa})$ and GAPDH (35kDa) polypeptides labeled with conjugated antibodies from pigs fed control and CLA supplemented diets. The proteins were isolated from muscle homogenates, separated on $10 \%$ SDS-PAGE and electroblotted to nitrocellulose membrane as mentioned in the material and methods section. Blots were colormetrically labeled using alkaline phosphatase to generate a NBT/BCIP signal. Western blot A) labeled PPAR $\alpha$ and GADPH signal B) mcalpain signal. Lanes 1-7 control diet, Lanes 8-14 CLA diet, std, SDS-PAGE prestained protein standard.

The adipocyte fatty acid binding protein (AFABP) is known to contain PPRE binding sites in its upstream promoter region $(23,24)$ and $2 \%$ CLA did increase AFABP gene expression (Fig. 2) in this trial by $26 \%(\mathrm{P}<0.05)$. Acyl-CoA oxidase (ACO) also contains a PPRE in it promoter and is expressed in both muscle and liver cells. However in rat studies (25), ACO mRNA is increased only in liver but not in muscle, by a CLA diet. The pig muscle ACO also did not show a significant response to dietary CLA. Since IMF adipose was not dissected from the lean muscle tissue for individual testing of RNA, it was possible that the observed increase in PPAR $\gamma$ expression was an artifact of the increased IMF\% in the LT muscle from the CLA fed group. To investigate the possibility of sampling variance, a muscle to fat ratio was calculated using the gene markers, m-calpain (muscle), and AFABP (adipocytes). There was still a significant increase in GFAT and PPAR $\gamma$ mRNA expression in the $2 \%$ CLA fed animals after adjusting for the relative level of fat in each muscle sample.

Recent pig studies have shown that prolonged dietary treatment with 3\% CLA increases the plasma fasted levels of both free fatty acids and insulin $(10,26)$. One of the effects from increased insulin sensitivity is increased protein retention due to reduced skeletal muscle catabolism (27). The protease mcalpain mRNA was measured to determine if dietary CLA reduced protein catabolism. The mRNA and protein level of mcalpain was not significantly reduced by CLA in this trial. Increased insulin activity also increases in the number of insulin receptors and glucose transporters (GLUT) on the plasma membrane of skeletal muscle (28). The net effect is increased intercellular glucose and reduced protein catabolism needed to supply glycogenic amino acids (29). Expression of GFAT mRNA in the hexosamine pathway is increased when an excess amount of intercellular glucose is available. GFAT mRNA expression was significantly increased in the CLA fed pigs. Antibodies for porcine GFAT protein were not available for comparison and plasma insulin levels were not measured in this trial. However, the increased GFAT mRNA expression did indicate that intercellular glucose and possibly plasma insulin was increased by the dietary CLA. This supports the hypothesis that feeding CLA to the pigs increased muscle insulin sensitivity causing an increase in muscle intercellular glucose, GFAT expression, and the hexosamine pathway (12).

To conclude, the semi-quantitative RT-PCR results show that prolonged dietary CLA increased gene transcription of PPAR $\gamma$, GFAT and AFABP in LT muscle core samples. The increased rate of gene transcription was not detected using western blotting techniques for these same genes but since the PPAR inducible AFABP gene was increased by CLA, it demonstrates that PPAR functional activity was increased in the muscle. Lean muscle mass and GFAT mRNA levels were also increased indicating that the intercellular supply of glucose was improved in the muscle of pigs fed CLA.

\section{ACKNOWLEDGMENTS}

A great deal of credit is owed to my molecular biology technician Robin MacInnis, who performed most of the final RT-PCR quantification trials. Dr. Mike Dugan discovered the initial beneficial application of CLA in pig diets. Dave Rolland and Sheri Nelson were essential as the main lipid biochemistry technician and herdsperson in the maintenance of the CLA diets. Agri-Food, Agriculture Canada supplied financial support for this work.

\section{REFERENCES}

1. Dugan MER, Aalhus JL, Schaefer AL, Kramer JKG. The effect of conjugated linoleic acid on fat to lean repartitioning and feed conversion in pigs. Canadian Journal of Animal Science 1997; 77:723-725.

2. Issemann I, Green S. Activation of a member of the steroid hormone receptor superfamily by peroxisome proliferators. Nature 1990; 347: 645-650.

3. Forman BM, Tontonoz P, Chen J, Brun RP, Spiegelman BM, Evans RM. 15-deoxy- $\delta^{12,14}$-prostaglandin $J_{2}$ is a ligand for the adipocyte determination factor PPAR $\gamma$. Cell 1995; 83: 803-812.

4. Oritz JA, Mallolas J, Nicot C, Bofarull J, Rodriguez JC, Hegardt FG, Haro D, Marrero PF. Isolation of pig mitochondrial 3-hydroxy-3-methylglutaryl-CoA synthase gene promoter: characterization of a peroxisome proliferator-responsive element. Biochemistry Journal 1999; 337: 329-335.

5. Mukherjee R, Jow L, Croston GE, Paterniti JR. Identification, characterization, and tissue distribution of human peroxisome proliferator-activated receptor (PPAR) isoforms PPAR $\gamma 2$ verses PPAR $\gamma 1$ and activation with 
retinoid $\mathrm{X}$ receptor agonists and antagonists. Journal of Biological Chemistry 1997; 272: 8071-8076.

6. Mandrup S, Lane MD. Regulating adipogenesis. Journal of Biological Chemistry 1997; 272: 5367-5370.

7. Braissant $\mathrm{O}$, Wahli $\mathrm{W}$. Differential expression of peroxisome proliferator-activated receptor $-\alpha,-\beta$, and $-\gamma$ during rat embryonic development. Endocrinology 1998; 139: 2748-2754.

8. Michalik L, Wahli W. Peroxisome proliferator-activated receptors: three isotypes for a multitude of functions. Current Opinion in Biotechnology 1999; 10: 564-570.

9. Bustin, SA. Invited review: Quanitification of mRNA using real-time reverese transcription PCR (RT-PCR): trends and problems. Journal of Molecular Endocrinology 2002; 29:23-39.

10. Stangl GI, Muller H, Kirchgessner M. Conjugated linoleic acid effects on circulating hormones, metabolites and lipoproteins, and its proportion in fasting serum and erythrocyte membranes of swine. European Journal of Nutrition 1999; 38: 271-277.

11. Wang J, Liu R, Hawkins M, Barzilai N, Rossetti L. A nutrient sensing pathway regulates leptin gene expression in muscle and fat. Nature 1998; 393: 684-688.

12. Hawkins M, Angelov I, Liu R, Barzilai N, Rossetti L. The tissue concentration of UDP-N-acetylglucosamine modulates the stimulatory effect of insulin on skeletal muscle glucose uptake. Journal of Biological Chemistry 1997; 272: 4889-4895.

13. Kramer JKG, Sehat N, Dugan MER, Mossoba MM, Yurawecz MP, Roach JAG, Eulitz K, Aalhus JL, Schaefer $\mathrm{AL}, \mathrm{Ku}$ Y. Distribution of conjugated linoleic acid (CLA) isomers in tissue lipid classes of pigs fed a commercial CLA mixture determined by gas chromatography and silver ion-high-performance liquid chromatography. Lipids 1998; 33: 549-558.

14. National Research Council. Nutrient requirements of swine. $9^{\text {th }}$ ed. National Academy Press, Washington, DC. 1998.

15. Canadian Council on Animal Care. Guide to the care and use of experimental animals. 1993. Vol.1 Ed. Olfert ED, Cross BM, McWilliam AA. CCAC, Ottawa, ON.

16. Martin AH, Fredeen HT, Weiss GM, Fortin A, Sim D. Yield of trimmed pork product in relation to weight and backfat thickness of the carcass. Canadian Journal of Animal Science 1981; 61: 299-310.

17. Association of Official Analytical Chemists. Official methods of AOAC international. $16^{\text {th }}$ ed. AOAC, Washington DC. 1995. Method 39.1.05.

18. Chomczynski P, Sacchi N. Single step method of RNA isolation by acid guanidinium thiocyanate-phenolchloroform extraction. Analytical Biochemistry 1987; 161: 156-159.

19. Meadus WJ, Macinnis R. Testing for the RN-gene in retail pork chops. Meat Science 2000; 54:231-237.

20. Spencer WE, Christensen MJ. Multiplex relative RT-PCR method for verification of differential gene expression. BioTechniques 1999; 27: 1044-1052.
21. Statistical Analysis System Institute. SAS user's guide: statistics, $5^{\text {th }}$ ed. SAS Institute Inc., Cary, NC. 1985.

22. Meadus WJ, MacInnis R, Dugan MER. Prolonged dietary treatment with conjugated linoleic acid stimuates porcine muscle peroxisome proliferator activated receptor $\mathrm{g}$ and glutamine fructose aminotransferase gene expression in vivo. Journal of Molecular Endocrinology 2002; 28: 7986.

23. Thoennes SR, Tate PL, Price TM, Kilgore MW. Differential transcriptional activation of peroxisome proliferator-activated receptor gamma by omega-3 and omega-6 fatty acids in MCF-7 cells. Molecular and Cellular Endocrinology 2000; 160: 67-73.

24. Gerbens F, de Koning DJ, Harders FL, Meuwissen THE, Janss LGG, Groenen MAM, Veerkamp JH, Van Arendonk JAM, te Pas MFW. The effect of adipocyte and heart fatty acid-binding protein genes on intramuscular fat and backfat content in Meishan crossbred pigs. Journal of Animal Science 2000; 78: 552-559.

25. Moya-Camarena SY, Belury MA. Species differences in the metabolism and regulation of gene expression by conjugated linoleic acid. Nutrition reviews 1999; 57: 336340.

26. Muller HL, Kirchgessner M, Roth FX, Stangl GI. Effect of conjugated linoleic acid on energy metabolism in growingfinishing pigs. Journal of Animal Physiology and Animal Nutrition 2000; 83: 85-94.

27. Rooyackers OE, Nair KS.Hormonal regulation of human muscle protein metabolism. Annual Review of Nutrition 1997; 17: 457-485.

28. Ezaki O. Regulatory elements in the insulin-responsive glucose transporter (GLUT4) gene. Biochemical and Biophysical Research Communication 1997; 241: 1-6.

29. Huang J, Forsberg NE. Role of calpain in skeletal-muscle protein degredation. Proceedings of the National Academy of Sciences USA 1998; 95: 12100-12105.

30. Altschul SF, Madden TL, Schaffer AA, Zhang J, Zhang Z, Miller W, Lipman DJ. Gapped BLAST and PSI-BLAST: a new generation of protein database search programs. Nucleic Acids Research 1997; 25:3389-3402. 
Table 1: Sequence, expected fragment size and annealing temperature (ta) of primers used in the semiquantitative RT-PCR analysis of mRNA levels of the genes expressed in porcine LT muscle.

\begin{tabular}{|c|c|c|c|c|}
\hline Gene & Sequences & $\begin{array}{l}\text { Expected } \\
\text { fragment } \\
\text { size (bp) }\end{array}$ & ta $\left({ }^{\circ} \mathrm{C}\right)$ & $\begin{array}{l}\text { GenBank } \\
\text { accession number }\end{array}$ \\
\hline PPAR $\alpha$ & 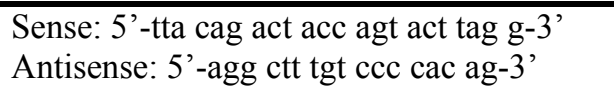 & 176 & 58 & AF175309 \\
\hline PPAR $\gamma$ & $\begin{array}{l}\text { Sense: } 5^{\prime} \text {-tga cca tgg ttg aca ccg-3' } \\
\text { Antisense: } 5^{\prime} \text {-aag cat gaa ctc cat agt gg-3' }\end{array}$ & 381 & 58 & SSC6756 \\
\hline $\begin{array}{l}\text { AFABP }(\mathrm{aP} 2) \\
\text { Exon } 1 \rightarrow 2\end{array}$ & $\begin{array}{l}\text { Sense: } 5^{\prime} \text {-tgg aaa ctt gtc tcc agt g-3' } \\
\text { Antisense: } 5^{\prime} \text {-ggt act ttc tga cta atg gtg-3' }\end{array}$ & 147 & 56 & SSY16039 \\
\hline Cyclophilin & $\begin{array}{l}\text { Sense: } 5^{\prime} \text {-acc gtc ttc ttc gac atc g-3', } \\
\text { Antisense: } 5^{\prime} \text {-caa cca ctc agt ctt ggc-3' }\end{array}$ & 330 & 62 & AY008846 \\
\hline $\begin{array}{l}\text { Calpain } 1 \\
\text { Exon } 1 \rightarrow 2\end{array}$ & $\begin{array}{l}\text { Sense: } 5 \text { '-tgg aag gac tgg agc ttt gt-3' } \\
\text { Antisense: } 5 \text { '-gac tcc agg gca tca gct g-3' }\end{array}$ & 152 & 60 & SSU23954 \\
\hline $\mathrm{ACO}$ & $\begin{array}{l}\text { Sense: } 5^{\prime} \text {-ccg gag ctg ctt aca cac at-3' } \\
\text { Antisense: } 5^{\prime} \text {-ggt cat acg tgg ctg tgg tt-3' }\end{array}$ & 427 & 60 & AF185048 \\
\hline GFAT & $\begin{array}{l}\text { Sense } 5 \text { '-aac cca gtc ctg tca ata gcc-3' } \\
\text { Antisense } 5 \text { '-acg aga gag att gca gct tcc-3' }\end{array}$ & 420 & 60 & AF441244 \\
\hline$\beta$-actin & $\begin{array}{l}\text { Sense: } 5^{\prime} \text {-gga ctt cga gca gga gat gg-3', } \\
\text { Antisense: } 5^{\prime} \text {-gca ccg tgt tgg cgt aga gg-3' }\end{array}$ & 233 & 61 & SSU07786 \\
\hline
\end{tabular}




\section{PROTOCOLS}

\section{Relative Reverse Transcriptase - Polymerase Chain Reaction (RT-PCR) analysis}

\section{Isolation and preparation of total RNA}

1. Total RNA was isolated from animal tissue frozen at $-80^{\circ} \mathrm{C}$. The tissue was collected immediately after slaughter in the Lacombe Research Centre meat abattoir according CCAC guidelines.

2. Each sample of RNA was collected from $100 \mathrm{mg}$ of tissue in $1000 \mathrm{ul}$ of TRIzol reagent (GIBCO-BRL, Burlington, ON, Canada). The tissue was thawed for 15min then homogenized using a Tissue Tearor (Biospec Products, Bartleville, OK) for $15 \mathrm{~s}$ at $30,000 \mathrm{rpm}$.

3. The homogenized samples were then mixed with $300 \mathrm{ul}$ of chloroform, vortexed for $10 \mathrm{~s}$ then centrifuged at $12,000 \mathrm{xg}$ for 10 min.

4. The aqueous phase was withdrawn to a new tube and mixed with $600 \mathrm{ul}$ isopropanol, and allowed to precipitate at $-20^{\circ} \mathrm{C}$ for $>$ 60 min.

5. The RNA preciptitate was pelleted by centrfugation at $12,000 \mathrm{xg}$ for $10 \mathrm{~min}$.

6. The RNA pellet was resuspended in $500 \mathrm{ul}$ Trizol for a second round of purification, mixing with $150 \mathrm{ul}$ chloroform, centrifugation at $12,000 \mathrm{xg}$ for $10 \mathrm{~min}$, collecting the aqueous phase and mixing with $1000 \mathrm{ul}$ ethanol. Precipitating at $-20^{\circ} \mathrm{C}$ for $>60 \mathrm{~min}$.

7. The RNA was again pelleted $12,000 \mathrm{xg}$ for $10 \mathrm{~min}$ and resuspended in $20 \mathrm{ul}$ of $100 \%$ deionized formamide. The formamide solution was heated at $85^{\circ} \mathrm{C}$ for $10 \mathrm{~min}$ to dissolve the pellet completely.

8. The quality of RNA was examined by runnning $2 \mathrm{ul}$ of the formamide solution on $1.5 \%$ agarose gels in TBE buffer [89mM Tris-base pH 7.6, $89 \mathrm{mM}$ boric acid, $2 \mathrm{mM}$ EDTA] stained with $10 \mathrm{ug} / \mathrm{ml}$ ethidium bromide. RNA quality was assessed by the sharpness of the $28 \mathrm{~S}$ and $18 \mathrm{~S}$ rRNA bands migrating at the $1000 \mathrm{bp}$ and $500 \mathrm{bp}$ molecular ladder standards range as visualized on a 330nm UV-transilluminator. Good quality RNA has a sharp 28S rRNA band with approximately 2-fold the intensity of the $18 \mathrm{~S}$ band and a $260 \mathrm{~nm} / 280 \mathrm{~nm}$ absorbance ratio close to 2.0 .

9. The yield of RNA was determined relative to the molecular ladder standard on the $1.5 \%$ agarose gel and by absorbance at 260 $\mathrm{nm}$ on a spectrophotometer. RNA concentration is estimated by the dilution factor X $50 \mathrm{ug} / \mathrm{ml}$ X OD260 nm.

\section{Generation of cDNA}

1. Complementary DNA was generated using appoximately 2 ug of total RNA in $<2.0$ uls of $100 \%$ formamide with 200 U of MMLV-reverse transcritiptase (Bio Basic Inc, Markham, ON), 10U Rnase inhibitor (Sigma, Oakville, ON), 10mM DTT, 40 $\mathrm{mM} \mathrm{KCl}, 6 \mathrm{mM} \mathrm{MgCl}_{2}, 50 \mathrm{mM}$ Tris-HCl pH 8.3, $0.5 \mathrm{mM}$ each of dTTP, dCTP, dGTP, and dATP, $400 \mathrm{mM}$ oligo (dT) ${ }_{12-18}$, and $200 \mathrm{mM}$ random nonamers in a $20 \mathrm{ul}$ reaction volume.

2. Preheating the RNA in the RT reaction buffer without the enzyme is not required if it was heated in the $100 \%$ formamide.

3. The RT reaction is first incubated at $20^{\circ} \mathrm{C}$ for $10 \mathrm{~min}$ to allow annealling of the random hexamers then incubated at $42^{\circ} \mathrm{C}$ for $60 \mathrm{~min}$.

4. The RT reaction is stopped by incubating at $95^{\circ} \mathrm{C}$ for $5 \mathrm{~min}$. Store at $-20^{\circ} \mathrm{C}$.

\section{Normalizing the cDNA stock samples}

1. To evaluate the quality and equalize the amount of cDNA from each sample, a PCR trial was made using the internal standards cyclophilin or $\beta$-actin.

2. Using $2.0 \mathrm{ul}$ of the $20 \mathrm{ul} \mathrm{RT}$ reaction, primers [5 uM] for $\beta$-actin or cyclophilin were mixed with $4 \mathrm{U}$ of REDTaq DNA polymerase (Sigma, Oakville, ON), $0.2 \mathrm{mM}$ each of dTTP, dCTP, dGTP, and dATP, into a total volume of 40 ul then divided into 4 tubes of $10 \mathrm{ul}$ each. The PCR program initially started with a $95^{\circ} \mathrm{C}$ denaturation for $5 \mathrm{~min}$, followed by 16 to 22 cycles of $95^{\circ} \mathrm{C} / 1 \mathrm{~min}$, ta ${ }^{\circ} \mathrm{C} / 1 \mathrm{~min}, 72^{\circ} \mathrm{C} / 1 \mathrm{~min}$. Polymerase chain reactions were performed on a PTC-200 PCR machine (MJ Research Inc, MA, USA)

3. The 10 ul PCR for $\beta$-actin or cyclophilin were amplified for 16, 18, 20, and 22 cycles, collecting one tube at each of the specified cycles at the end of the $72^{\circ} \mathrm{C}$ extention phase.

4. The PCR samples were run on either $2 \%$ agarose or $8 \%$ native polyacrylamide gels in TBE gels then stained with ethidium bromide for visualization on a UV transilluminator. The $\beta$-actin and cyclophilin primers also produce larger PCR products from genomic DNA and therefore could also be used to assess the amount of contaminating DNA in the cDNA preparation. 
5. The UV illuminated gel images were digitally captured with a CCD-camera (Coho, Japan) using the Scion/NIH Imager program (Scion Corp. MA). The quantity of cyclophilin or $\beta$-actin PCR DNA fragments were estimated according to band intesity using the One-Dscan software (Scanalytics, Fairfax, VA).

6. Samples densities from the 16 to 22 cycles were plotted to find the linear amplification range, which was typically in between 18 and 22 cycles. A minimal signal density for 20 cycles is then chosen as the baseline and then the cDNAs are adjusted to all give the same signal strength for $\beta$-actin when amplifying $1 \mathrm{ul}$ of the adjusted cDNA stock.

7. Standardization of the cDNAs is also double checked using cyclophilin as the internal control.

\section{Preparation of primers for RT-PCR analysis}

1. Oligonucleotide primers are designed to amplify across intron regions so only the RT prepared cDNA wil give PCR products. The primers are tested on genomic DNA templates to guarantee against false PCR signals from psuedogenes and possible contaminating DNA in the RT cDNA samples.

2. Intial PCR products for each gene were cloned into pCR2.1 plasmids using the TA cloning kit (Invitrogen Corp., Carlsbad, CA). The cloned products were sequenced using the ABI Prism Big Dye terminator cycle sequencing ready reaction kit (Applied Biosystems, Foster city, CA) and compared against GenBank (NIH, Bethesda., MD) using the BLAST program (30) to confirm identity. New porcine sequences were considered identified if they were $>85 \%$ homologous against human or mouse sequences and had an expected false positive probability value $\mathrm{P}<0.0001$.

3. The optimum annealing temperature and linear amplification range for each gene specific primer pair was predetermined using $1 \mathrm{ul}$ of standardized cDNA per $20 \mathrm{ul} \mathrm{PCR}$ assay. Some of the lower expressed genes like PPAR $\alpha$ and PPAR $\gamma$ required $>32$ cycles of PCR amplification to be detected on the ethidium bromide stained $8 \%$ polyacrylamide gels.

\section{Relative semi-quantitative PCR}

1. To quantitate the relative amount of gene transcription for each treatement, $1 \mathrm{ul}$ of the standardized cDNA was used in a $20 \mathrm{ul}$ PCR solution and cycled to within the predetermined linear amplification range. At 20 cycles before the end of the last cycle, primers for the housekeeping genes b-actin or cyclophlin were added at the end of the $72 \mathrm{C}$ extention phase. This would then generate PCR products for the target gene and the housekeeping gene both within their linear amplification range.

2. The PCR products were separated and visualized on either $2 \%$ agarose or $8 \%$ PAGE and digitally recorded as previously described.

3. Gene expression was determined relative to the internal standard PCR signal. Comparison of target gene expression between individuals was adjusted according to the internal standards which were previously normalized between samples.

4. The proceedure was repeated and the values combined to determine averages and statistical differences.

\section{Protein isolation and analysis}

1. Proteins were extracted from the thawed muscle samples by homogenizing $100 \mathrm{mg}$ of muscle in $1 \mathrm{ml}$ of extract buffer A [100 $\mathrm{mM}$ Tris- $\mathrm{HCl} \mathrm{pH}$ 7.5, $0.5 \mathrm{mM}$ dithiothreitol, $2 \mathrm{mM}$ phenymethylsulfonyl flouride (PMSF), $5 \mathrm{mM}$ ethylenediaminetetraacetic acid (EDTA), $500 \mathrm{mM} \mathrm{NaCl}$, and $0.1 \%$ Triton X-100.

2. The homogenate was then centrifuged at $1000 \mathrm{xg}$ for $5 \mathrm{~min}$ to pellet large cellular debris. Protein concentrations were measured at A562nm using the rapid Bicinchoninic acid (BCA) assay (Pierce, Rockford, IL). Protein concentrations are estimated relative to a $2 \mathrm{mg} / \mathrm{ml}$ BSA generated standard curve.

3. Samples were diluted to $1 \mu \mathrm{g} / \mathrm{ul}$ with extract buffer and then $20 \mu \mathrm{g}$ were mixed with an equal volume of SDS-PAGE loading buffer [50 mM Tris- $\mathrm{HCl} \mathrm{pH} 6.8,10 \%$ glycerol, $2 \%$ SDS, $5 \% \beta$-mercaptoethanol, $0.002 \%$ bromophenol blue], heated at 90C for 5 min then loaded onto $10 \%$ SDS-PAGE $(10 \times 15 \mathrm{~cm})$ with a $4 \%$ polyacrylamide stacker layer for 3 hours at $70 \mathrm{v}$ in TBE buffer. SDS-PAGE prestained protein standards (BioRad, Hercules, CA) were included to monitor electrophoresis.

4. The separated proteins were Western blotted from the 10\%PAGE to Protran nitrocellulose for $12 \mathrm{hr}$ at 0.1 amps (Schleicher, Schuell, Keene, NH) using a Trans-blot electrophoretic transfer cell in electroblot buffer [192 mM glycine, $25 \mathrm{mM}$ Tris, 20\% methanol, $0.1 \%$ SDS]. Electrophoretic transfer efficiency was determined by the amount prestained SDS-PAGE standards on the Protran blot after transfer.

5. The PPAR, m-calpain, and GADPH proteins were labeled using rabbit anti-PPAR $\gamma[5.0 \mathrm{ug} / \mathrm{ml}]$ (Sigma, St Louis, MO), goat polyclonal anti-PPAR $\alpha$ [2.0 ug/ml] (Santa Cruz biotechnology, Inc., Santa Cruz, CA), rabbit anti-m-calpain [3.0 ug/ml] (Sigma, St Louis, MO), or mouse anti-GAPDH $[2.0 \mathrm{ug} / \mathrm{ml}]$ (Chemicon Intl. Inc, Temecula, CA). The primary antibodies were diluted in TBS hybridization buffer [ $10 \mathrm{mM}$ Tris, $0.9 \% \mathrm{NaCl}, 0.05 \%$ Tween 20$]$ plus $10 \%$ carnation instant powdered skim milk adjusted to $\mathrm{pH} 7.5$ ] using approximately $10 \mathrm{ml}$ per $20 \mathrm{X} 20 \mathrm{~cm}$ blot.

6. Primary antibody hybridizations were incubated at $20^{\circ} \mathrm{C}$ for $>12 \mathrm{hrs}$. 
7. The blots were washed 6 times with TBS for 5 min each wash.

8. Primary antibodies were tagged with goat anti- rabbit IgG (Chemicon Intl. Inc, Temecula, CA), rabbit anti-goat IgG (Sigma, St Louis, MO), or chicken anti-mouse IgG antibodies (Chemicon Intl. Inc, Temecula, CA) conjugated with alkaline phosphatase. The anti-IgG antibodies were diluted 1000X in TBS hybridization buffer and incubated with the blots at $20^{\circ} \mathrm{C}$ for $1 \mathrm{hr}$.

9. The blots were then washed $6 \mathrm{X}$ in TBS and then soaked in Detection buffer $[100 \mathrm{mM}$ Tris $\mathrm{pH} 9.5,100 \mathrm{mM} \mathrm{NaCl}, 50 \mathrm{mM}$ $\mathrm{MgCl}_{2}$ ] for $5 \mathrm{~min}$.

10. Blots were incubated overnight at $20^{\circ} \mathrm{C}$ in $10 \mathrm{ml}$ detection buffer $+\mathrm{NBT} / \mathrm{BCIP}[0.4 \mathrm{mg} / \mathrm{ml}$ nitroblue tetrazolium chloride + $0.19 \mathrm{mg} / \mathrm{ml} \mathrm{5-bromo-4-chloro-3-indolyl-phosphate,} \mathrm{toludine-salt]} \mathrm{to} \mathrm{develop} \mathrm{blue} \mathrm{colored} \mathrm{bands} \mathrm{of} \mathrm{antibody} \mathrm{bound} \mathrm{proteins.}$ Colour development was stopped by rinsing with deionized water.

11. Proteins labeled by the alkaline phosphatase colour precipitation were digitally captured and quantitated under white light using a Hewlett-Packard 5100c scanner (Palo Alto, CA) and NIH imager program as previously described in the "Standardizing the cDNA stock samples" section. Polypeptide identification was also confirmed by molecular mass by comparing with the SDS-PAGE protein standards on the same blots. 